Hill, Dr M Lucas, Dr M Ridler, and Dr J Taylor for identifying the index patients and controls and Mrs Nora Jones for arranging for the collection of samples in Oxford. We are especially grateful to the patients who agreed to be included in the study and the late Professor Sir Alec Turnbull and other obstetricians who approached patients on our behalf and agreed to our interviewing them. The study was supported by Action Research for the Crippled Child.

1 Wald NJ, Cuckle HS, Densem JW, et al. Maternal serum screening for Down's syndrome in early pregnancy. Br Med f 1988;297:883-7.

2 Bartels I, Lindemann A. Maternal levels of pregnancy-specific beta ${ }_{1}$-glycoprotein (SP-1) are elevated in pregnancies affected by Down's syndrome. Hum Genet 1989;80:46-8.
Wald NJ, Cuckle HS, Densem J. Maternal serum specific beta ${ }_{1}$-glycoprotein in pregnancies associated with Down's syndrome. Lancet 1989;ii:450.

Cuckle HS, Wald NJ, Densem JW, et al. The effect of smoking in pregnancy on maternal serum alpha-fetoprotein, unconjugated oestriol, human chorionic gonadotrophin, progesterone and dehyroepiandrosterone sulphate levels. Brf Obstet Gynaecol 1990;97:272-6.

Grozdea J, Vergnes H, Martin J. Urea-resistant neutrophil alkaline phosphatase in mothers with trisomy 21 pregnancy. Lancet 1983;ii:799.

6 Grozdea J, Maret A, Vergnes H, et al. Cytochemical and biochemical studies on neutrophil alkaline phosphatase in parents of trisomy 21 children. Hum Gene 1984;67:313-6.

7 Kaplow LS. Cytochemistry of leucocyte alkaline phosphatase. Am f Clin Pathol 1963;39:439-49.

8 Krone A, Wolf U. The biochemical genetics of man. London: Academic Press, 1972.

(Accepted 1 August 1990)

\title{
Accuracy of clinical diagnosis of Alzheimer's disease
}

\author{
Alistair Burns, Philip Luthert, Raymond \\ Levy, Robin Jacoby, Peter Lantos
}

\section{Institute of Psychiatry,}

London SE5 8AF

Alistair Burns, MRCPSYCH,

honorary lecturer, section of old age psychiatry

Philip Luthert, MRCPATH, senior lecturer, department of

Raymond Levy, FRCPSYCH, professor of old age psychiatry

Robin Jacoby, FRCPSYCH, consultant psychiatrist, section of old age psychiatry Peter Lantos, FRCPATH, professor of neuropathology

Correspondence to: $\mathrm{Dr}$ Burns.

BrMed f 1990;301:1026 neuropathology

There is no specific antemortem marker for Alzheimer's disease, and the diagnosis may be uncertain even after examination of cerebral tissue. ${ }^{1}$ In 1988 Homer et al emphasised the problems of correctly predicting the pathological findings in various types of dementia and implied that Alzheimer's disease was often not confirmed at necropsy. ${ }^{2}$ The aim of our study was to assess prospectively the ability of current rigorous clinical criteria to diagnose Alzheimer's disease successfully during life.

\section{Patients, methods, and results}

We studied elderly psychiatric patients living in the area covered by Camberwell Health Authority, London. Altogether 180 were enrolled in the study, of whom 86 had died by three years. Necropsy was performed on 54 patients, and we report here on the first 50 .

The clinical criteria used were those of the National Institute of Neurological and Communicative Disorders and Stroke and the Alzheimer's Disease and Related Disorders Association. ${ }^{3}$ Probable Alzheimer's disease was diagnosed in patients with a history of a slowly progressive dementia without concomitant physical illness. Possible Alzheimer's disease was diagnosed in patients with atypical features of the disease or physical illness. Definite Alzheimer's disease was diagnosed only when the disease was confirmed by histopathological examination - that is, by the finding of widespread neocortical and hippocampal disease with plaques or neurofibrillary tangles, or both. Diffuse Lewy body disease was diagnosed when Lewy bodies were found not only in the substantia nigra and

Relation between diagnosis of Alzheimer's disease (probable or possible) based on clinical criteria and neuropathological diagnosis, and ability of clinical criteria to predict neuropathological findings of Alzheimer's disease and exclude vascular disease

\begin{tabular}{|c|c|c|c|}
\hline & \multicolumn{2}{|c|}{$\begin{array}{l}\text { Diagnosis of Alzheimer's disease from } \\
\text { clinical criteria }\end{array}$} & \multirow[b]{2}{*}{ Total $(n=50)$} \\
\hline & Probable $(\mathrm{n}=32)$ & Possible $(n=18)$ & \\
\hline \multicolumn{4}{|l|}{ Neuropathological diagnosis: } \\
\hline Alzheimer's disease alone & 24 & 10 & 34 \\
\hline Alzheimer's disease and vascular disease & 2 & 3 & 5 \\
\hline Alzheimer's disease and cortical Lewy & & & \\
\hline body disease & 2 & 1 & 3 \\
\hline Vascular disease alone & & 2 & 2 \\
\hline Cortical Lewy body disease alone & 3 & & 3 \\
\hline No diagnosis & 1 & 2 & 3 \\
\hline \multicolumn{4}{|c|}{$\begin{array}{l}\text { Ability of clinical criteria to predict pathological } \\
\text { findings of Alzheimer's disease: }\end{array}$} \\
\hline Findings present & 28 & 14 & 42 \\
\hline Findings absent & 4 & 4 & 8 \\
\hline \multicolumn{4}{|c|}{ Ability of clinical criteria to exclude vascular disease: } \\
\hline Vascular disease absent & 30 & 13 & 43 \\
\hline Vascular disease present & 2 & 5 & 7 \\
\hline
\end{tabular}

locus coeruleus but also in the cortex, particularly in the parahippocampal gyrus. Vascular damage was considered to be important when multiple, widespread macroscopic or microscopic lesions were identified.

The average age of the 50 patients studied was $82 \cdot 3$ years (range 70-99). The table shows the numbers of patients predicted by the clinical criteria to have probable and possible Alzheimer's disease and the neuropathological diagnoses. The criteria for predicting probable Alzheimer's disease had a sensitivity of $88 \%(28 / 32)$, and those for predicting possible Alzheimer's disease had a sensitivity of $78 \%$ (14/18). We could not assess specificity as we did not include in the study patients who did not satisfy the clinical criteria for the disease. The table also shows the ability of the criteria to exclude patients with vascular disease. Two patients had evidence of only vascular disease; in both cases the criteria had predicted possible Alzheimer's disease.

\section{Comment}

The main finding of this study was that Alzheimer's disease can be diagnosed accurately during life by strictly applying the criteria of the National Institute of Neurological and Communicative Disorders and Stroke and the Alzheimer's Disease and Related Disorders Association without the need for extensive investigation and resources. The rate of agreement between clinical and histological diagnoses of the disease varies from $50 \%{ }^{2}$ to over $95 \%,{ }^{4}$ but studies in which agreement has been $90 \%$ or above have all used the criteria that we used here. This is the first study to attempt to validate the criteria for possible Alzheimer's disease; it shows that the disease may be diagnosed in patients with other physical illness (such as diabetes and hypertension).

Cortical Lewy body disease was found in six patients (12\%), a prevalence similar to that found by Perry $e t$ $a l,{ }^{5}$ which suggests that this disease is the second commonest neurodegenerative dementia in old age.

The ability of the clinical criteria that we used to diagnose Alzheimer's disease in $88 \%$ of patients confirms their validity. Such successful clinical prediction of disease is unusual in any branch of medicine.

This work was supported by grants from the Medical Research Council to RL, RJ, and the institute's brain bank in the department of neuropathology.

\footnotetext{
Wisniewski H, Rabe A, Zigman W, Silverman W. Neuropathological diagnosis of Alzheimer's disease. I Neuropathol Exp Neurol 1989;48:606-9.

Homer A, Honavar M, Lantos P, Hastie I, Kellett J, Millard P. Diagnosing dementia: do we get it right? $\mathrm{Br}$ Med $\mathcal{f}$ 1988;297:894-6.

3 McKhann G, Drachman D, Folstein M, Katzman R, Price D, Stadlan E. Clinical diagnosis of Alzheimer's disease: report of the NINCDS/ADRDA workgroup under the auspices of Department of Health and Human Services task force on Alzheimer's disease. Neurology 1984;34:939-44.

4 Martin E, Wilson R, Penn R, Fox J, Clasen R, Savoy S. Cortical biopsy results in Alzheimer's disease: correlation with cognitive deficits. Neurology 1987:37: $1201-4$

5 Perry R, Irving D, Blessed G, Perry E, Fairbairn A. Clinically and neuropathologically distinct form of dementia in the elderly. Lancet 1989;i:166.
}

(Accepted 13 fulv 1990$)$ 